\title{
Negative regulation of STAT92E by an N-terminally truncated STAT protein derived from an alternative promoter site
}

\author{
Melissa A. Henriksen, ${ }^{1}$ Aurel Betz, ${ }^{1}$ Marc V. Fuccillo, and James E. Darnell, Jr. ${ }^{2}$ \\ Laboratory of Molecular Cell Biology, The Rockefeller University, New York, New York 10021, USA
}

\begin{abstract}
Previously unrecognized mRNAs originating from a dual promoter at the stat92E locus are described. One of these encodes a truncated protein, $\triangle$ NSTAT92E, that lacks the $\mathrm{N}$-terminal 133 amino acids. Antibodies detect both the full-length and truncated molecules early in embryogenesis (1-5 h), and mRNA detection by specific RT-PCR reactions accords with the protein distribution. Given that the $\mathbf{N}$ termini of mammalian STATs are known to have positive functions in transcriptional activation, we explored the role of $\triangle$ NSTAT92E early in embryogenesis. By increasing the $\triangle$ NSTAT92E-to-STAT92E ratio in overexpression and RNAi experiments, we observe phenotypes compatible with suppression of wild-type STAT92E activity. We therefore conclude that the short form of STAT92E is a naturally occurring dominant-negative product that can be added to the growing list of negative regulators of STAT activity.
\end{abstract}

[Keywords: Drosophila melanogaster; STAT92E; alternative promoters; differential splicing]

Received July 2, 2002; revised version accepted July 18, 2002.

In response to more than 40 different polypeptides, one or more of seven known mammalian STAT (signal transducers and activators of transcription) transcription factors becomes phosphorylated on tyrosine, dimerizes, and enters the nucleus (Darnell 1997; Stark et al. 1998; Levy and Darnell 2002). Transcriptional activation by the STATs affects growth, differentiation, and the immune response, as well as resistance to infection mediated by interferons (IFNs), through the study of which they were discovered (Darnell et al. 1994). How such a diversity of biological functions is achieved by a relatively small group of transcription factors is still unknown. Cooperation with other transcription factors (Look et al. 1995; Stocklin et al. 1996; Zhang et al. 1999; Levy and Darnell 2002) while bound at closely spaced sites on DNA in so-called enhanceosomes (Carey 1998) likely increases the transcriptional potential of activated STATs.

On the other hand, there are a series of proteins that have the capacity to act as inhibitors of STAT function and in so doing deliver a balanced amount of STAT-dependent transcriptional activation. The negative-acting proteins include cytoplasmic tyrosine phosphatases and proteins termed SOCS and CIS whose genes are induced by cytokines (Starr and Hilton 1999; Krebs and Hilton 2001). The induced SOCS and CIS proteins inhibit STAT tyrosine phosphorylation by binding to kinases or recep-

\footnotetext{
${ }^{1}$ These authors contributed equally to this work.

${ }^{2}$ Corresponding author.

E-MAIL darnell@rockvax.rockefeller.edu; FAX (212) 327-8801.

Article and publication are at http://www.genesdev.org/cgi/doi/10.1101/ gad.1020702.
}

tors, completing a negative feedback loop. In the nucleus there are tyrosine phosphatases (Haspel and Darnell 1999; ten Hoeve et al. 2002) and PIAS proteins (Shuai 2000) that negatively regulate already activated STATs by either removing the tyrosine phosphate or binding to phosphorylated STATs and blocking their DNA-binding.

An additional potential mechanism for regulating the transcriptional impact of seven chromosomal loci is the generation of multiple proteins from the differential processing of a primary transcript. In fact, the first described STAT family member, Stat 1 , is produced as a full-length protein (750 residues) called Stat $1 \alpha$ and as a C-terminally truncated protein $(712$ residues) called Stat $1 \beta$. The stat $1 \beta$ mRNA results from a differential poly(A) site choice, which dictates different $3^{\prime}$ splicing. The stat $1 \alpha$ mRNA has a terminal exon (Schindler et al. 1992; Muller et al. 1993) encoding 38 amino acids that act as a transcriptional activation domain (TAD). Omission of these 38 amino acids in STAT1 $\beta$ cause it to fail in transcriptional activation. Shorter forms lacking the TAD of both Stat3 and Stat5 also exist (Schaefer et al. 1995, 1997; Wang et al. 1996). STAT1 $\beta$, STAT3 $\beta$, and STAT5 $\beta$ when overexpressed have a dominant-negative effect (Stark et al. 1998; Bromberg and Darnell 2000). Furthermore, mice lacking specifically STAT3 $\beta$ have inaccurate regulation of the acute-phase response in the liver (Yoo et al. 2002).

In Drosophila, one STAT gene locus, stat92E, has been identified from which two extremely similar alternative splicing products are known to arise; one, 761 amino acids in length, contains seven residues in the region upstream of the tyrosine phosphorylation site that the 
other lacks (Hou et al. 1996; Yan et al. 1996b). In our original description of the STAT92E protein, we observed, using Schneider cell extracts, not one but three inducible phosphotyrosine-containing DNA-protein complexes that cannot be accounted for by the sevenresidue difference. The largest of these represented dimers of the full-length STAT92E protein. The nature of the two faster-migrating DNA-protein complexes was not clear. However, we suggested the possibility of a significantly shorter STAT molecule $(\sim 70-80 \mathrm{kD})$ that could dimerize and bind DNA and also pair with the longer molecule to form a heterodimeric DNA-binding complex of intermediate mobility.

Here we describe mRNAs with different $5^{\prime}$ exons that arise from two different primary transcripts at the stat92E locus. When processed, these primary transcripts yield several different mRNAs, some of which encode a protein lacking the $\mathrm{N}$-terminal STAT domain (amino acids 1-134). The existence of the shorter protein is shown with specific anti-sera. This shorter protein, when phosphorylated and bound to DNA, produces the faster-migrating DNA-protein complex that was observed earlier.

The $\mathrm{N}$ termini of mammalian STATs have several established roles in STAT transcriptional activation (Levy and Darnell 2002). Therefore, we tested the function of $\triangle$ NSTAT92E in two assays in early development. Overexpression of $\Delta$ NSTAT92E and specific suppression, by RNAi, of all stat92E mRNA or specifically mRNA encoding the full-length protein, both produce phenotypes compatible with a negative function for $\triangle$ NSTAT92E in development. Because of the variation of these isoforms during development, we propose that $\Delta$ NSTAT92E may act as a regulated damper on the transcriptional activator STAT92E.

\section{Results}

Western blotting and EMSA of S2 cell, embryo, and larvae nuclear extracts

The existence of an alternative form of STAT92E was first suggested because nuclear extracts from vanadate$\mathrm{H}_{2} \mathrm{O}_{2}$-treated Drosophila Schneider (S2) cells produced three DNA-protein complexes in electrophoretic mobility shift assays (EMSA; labeled A, B, and C, with A being the slowest-migrating band) using an optimized DNAbinding-site oligonucleotide probe (Yan et al. 1996b). The $\mathrm{A}$ and $\mathrm{B}$ complexes were increased upon transfection of the cells with a STAT92E-containing plasmid that incorporated a Flag epitope tag. Only complexes A and B were supershifted by the antibody to the epitope tag. These experiments established that the $86-\mathrm{kD}$ protein encoded by the stat92E cDNA was responsible for complex A and possibly contributed, as a heterodimer with another STAT protein, to complex B. The nature of the C complex became the target of this study. (As is discussed below, the finding of three bands, A, B, and C, is repeated in Fig. 2, below, where Schneider cell extracts from nontransfected cells were used.)
Antibodies were produced to several domains of the STAT92E protein, two of which were used in the Western blots in Figure 1. The antibody to the $\mathrm{N}$ terminus (residues 1-134, denoted $\alpha-\mathrm{NT}$ ) reacted with a protein the same size as the Flag-tagged STAT92E construct prepared in the original experiments. The antibody (labeled $\alpha$-CC) against residues $135-338$, the region of the STAT92E protein expected to lie in the coiled-coil domain of a generalized STAT structure (Becker et al. 1998; Chen et al. 1998), reacted with both the full-length 86$\mathrm{kD}$ molecule and also with a shorter $\sim 70-\mathrm{kD}$ molecule. Both the $86-\mathrm{kD}$ and $70-\mathrm{kD}$ molecules were present in S2 cell extracts and in extracts from $0-5$-h embryos. Both proteins emanate from transcription of the stat92E gene, because neither protein was observed in first-instar larvae homozygous for the stat92E null allele, stat92E ${ }^{06346}$. This allele lacks stat92E mRNA because of a P-element insertion upstream of the gene (Hou et al. 1996). This result was made possible by creating the fly stock, stat92E ${ }^{06346} / T M 3, A c t-G F P$ (for parental stocks and crosses, see Materials and Methods section) so that homozygous null larvae with the lowest maternal STAT92E levels could be selected late in development but before they die. The $\alpha$-CC antibody only reacted with extract from wild-type or heterozygous larvae but not with extract prepared from homozygous stat $92 E^{-/-}$null first-instar larvae (Fig. 1, cf. lanes 6 and 7). The $70-\mathrm{kD}$ band was much more prominent than the $86-\mathrm{kD}$ band at first instar. We concluded that the $70-\mathrm{kD}$ form was most likely an N-terminal truncation of STAT92E (DNSTAT92E) and not another STAT family member.

To correlate the existence of a shorter N-terminally truncated protein with the DNA-binding behavior observed earlier, gel shift assays were used. S2 cells were grown and treated with vanadate-peroxide for $15 \mathrm{~min}$, which is known to cause accumulation of tyrosine-phosphorylated STAT92E molecules (Yan et al. 1996b). Extracts were then prepared from these cells, from 1-5-h embryos, and from first-instar larvae. The $\alpha$-NT serum,

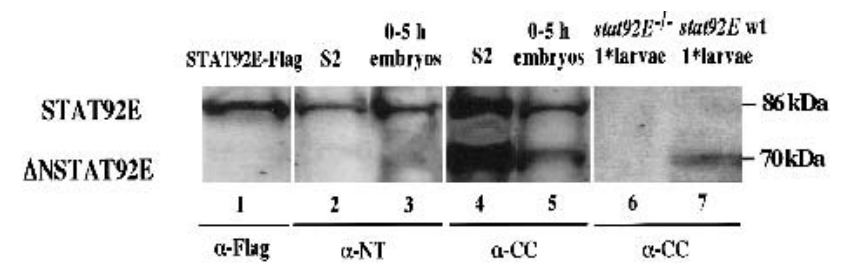

Figure 1. Western blot of nuclear extracts from S2 cells, 1-5-h embryos, and first-instar larvae. The anti-serum used is indicated under each panel. S2 cells and 1-5-h embryos express both full-length and an N-terminally truncated form of STAT92E (lanes 2-5). In first-instar $\left(1^{\star}\right)$ larvae that are stat92E $E^{-/-}$null mutants, no STAT92E is detected as compared with wild-type larvae, showing that the faster-migrating band is not caused by cross-reaction with a protein other than STAT92E (lane 6). Wild-type first-instar larvae predominantly express the N-terminally truncated form of STAT92E (lane 7). Flag-tagged recombinant STAT92E was transfected into S2 cells, and the extract was run simultaneously but blotted with Flag antibody separately, to indicate the position of full-length STAT92E (lane 1). 
the $\alpha$-CC serum, or $100 \times$ cold oligonucleotide was added to test the reactivity of the various DNA:protein complexes (Fig. 2). In the S2 and embryo extracts, complexes A, B, and C were present (Fig. 2, lanes 2,6) and could be competed with $100 \times$ cold oligonucleotide (Fig. 2, lanes $1,5)$, indicating specificity for the STAT92E DNA-binding site. All three complexes could be supershifted with the $\alpha$-CC serum (Fig. 2, lanes 4,8), whereas the $\alpha$-NT serum supershifted complexes A and B but not C (Fig. 2, lanes 3,7$)$. In extracts from first-instar larvae, only the $C$ band could be detected, in agreement with the antibody identification of an N-terminal truncation of STAT92E (cf. Fig. 1, lane 7, and Fig. 2, lane 10). The $\alpha$-CC serum supershifted this complex (Fig. 2, cf. lanes 11 and 12). Thus, the EMSA C complex appears to be a homodimer of the N-terminally truncated form of STAT92E, and the A complex a homodimer of full-length STAT92E, with the B complex representing a heterodimer of these two proteins.

\section{BLAST sequence similarity searches identify STAT92E} short-form clones

We next sought to establish the existence of sequences in the Drosophila genome that would give rise to the shorter form and to compare them to the pattern of exons for the full-length protein. The Drosophila EST database contained potential cDNA sequences (Rubin et al. 2000) that encoded a STAT92E protein lacking N-terminal residues. Using the sequence of the $5^{\prime}$-UTR and the nucleotides encoding the first 150 amino acids as input data, three cDNA clones possessing a sequence not in the original stat92E cDNA were identified (Table 1). This new sequence, which we called Exon 1a (for 1 alternate), was used subsequently as input data, and several more clones containing this sequence were defined. In clones LP02469 and LD47212, Exon 1a replaces Exons 1 and 2, and the mRNA sequence predicts a protein lacking the $\mathrm{N}$-terminal domain with a molecular mass of 71 $\mathrm{kD}$, translating from the first AUG with a Kozak sequence (Kozak 1991). In the other clones, Exon 1a replaces Exon 1 but retains Exon 2, and a full-length STAT92E protein is predicted from the longest open reading frame. LP02469 and LD47212 were sequenced, and it was determined that the former contained stat $92 E$ cDNA complete to the $\mathrm{C}$ terminus, including the seven- residue insert EPEPLVL at amino acid 698 (full-length STAT92E numbering).

The genomic location of Exons 1 and 1a relative to each other and to Exon 2 was revealed in a search of the Drosophila genomic sequence. The only matching STAT sequences were in a region embracing stat92E (GenBank accession no. AE003731), and the order, 5' to 3', of Exon $1>$ Exon 1 a > Exon 2 was established.

\section{Expression of $\Delta$ NSTAT92E in cultured S2 cells}

To show that the $\triangle$ NSTAT92E protein predicted by the cDNA of clone LP02469 can, indeed, be expressed from this cDNA, we transferred the entire clone to an $\mathrm{S} 2$ cell expression vector (pMT/V5-His C) that adds a His tag and is inducible by $\mathrm{CuSO}_{4}$. After transient transfection and induction, protein extracts were prepared and subjected to SDS-PAGE, followed by Western blotting with anti-His antibody. $\mathrm{A} \mathrm{CuSO}_{4}$-inducible and His-tagged protein of molecular mass $73 \mathrm{kD}$ was observed (Fig. 3A, lane 5; the V5-His tag adds $2.6 \mathrm{kD})$. The same extracts also reacted in a Western blot using $\alpha$-CC serum (Fig. $3 \mathrm{~B})$. The inducible $73-\mathrm{kD}$ protein reacted with the $\alpha$-CC antibody, confirming that the $\triangle$ NSTAT92E protein is expressed stably in S2 cells from the cloned cDNA LP02469, where Exon 1a is joined to Exon 3, replacing Exons 1 and 2.

\section{Alternative promoter use and differential splicing generate several stat92E transcripts}

To determine independently that we could recover previously registered mRNAs and to support the antibody findings of Figures 1 and 2, RT-PCR was performed using poly $(\mathrm{A})^{+}$RNA from embryos, larvae, or adult flies as well as total RNA from S2 cells. Primers were designed to anneal to Exon 1a (Primer A), Exon 2 (Primer C), and Exon 3 (Primer B). The presence of the $\Delta$ Nstat92E mRNA and of an mRNA encoding the $86-\mathrm{kD}$ protein both originating from the second promoter between Exons 1 and 2 was indicated by the amplification of two products with the primer pair A/B, with sizes of $1047 \mathrm{bp}$ and $734 \mathrm{bp}$ (Fig. 4A, lane 1). The primer pair C/B was used as the positive control, and one product of $650 \mathrm{bp}$ was observed as expected. (Only the gel containing embryo RNA reactions is shown, although identical results were observed for the other mRNA samples.) In Figure

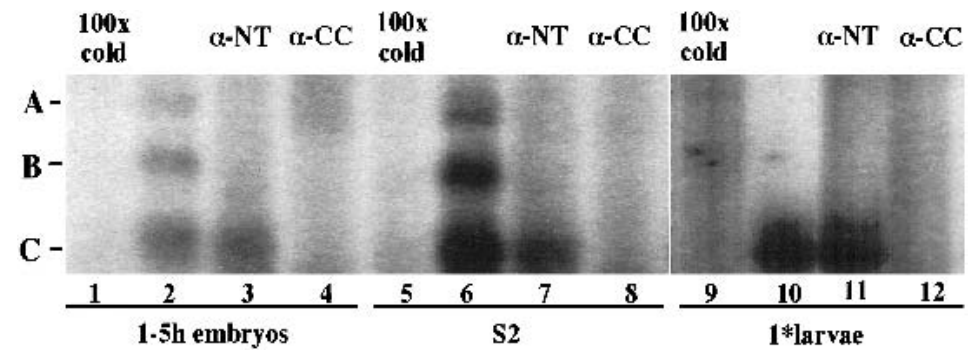

arvae only the short form is observed as a, B, C described in the text (lanes 2,6). In first-instar tiserum targeting the $\mathrm{N}$ terminus supershifts complexes $\mathrm{A}$ and B but not C (lanes 3,7,11), whereas the antiserum targeting the coiled-coil region supershifts all three complexes (lanes $4,8,12)$.
Figure 2. STAT92E-specific DNA-protein complexes in EMSA of extracts using the optimal STAT92E binding site oligonucleotide. Nuclear extract from 1-5-h embryos (lanes 1-4) and from S2 cells (lanes 5-8) and whole-cell extracts of 24-36-h first-instar larvae (lanes 9-12) were used. The extracts were incubated with either $100 \times$ cold oligonucleotide or the $\alpha$-NT or $\alpha$-CC antibodies. In 1-5-h embryos and S2 cells, the full-length and the N-terminally truncated forms of STAT92E are activated, bind DNA and form the homo- and heterodimeric complexes A, B , C described in the text (lanes 2,6). In first-instar 
Henriksen et al.

Table 1. BLAST sequence similarity searches

\begin{tabular}{|c|c|c|c|c|}
\hline $\begin{array}{l}\text { Accession } \\
\text { number }\end{array}$ & $\begin{array}{l}\text { Clone } \\
\text { ID }\end{array}$ & Library & $\begin{array}{l}\text { EST exon } \\
\text { structure }\end{array}$ & $\begin{array}{c}\text { Input } \\
\text { data }\end{array}$ \\
\hline AA948793 & LD27431 & Embryo & $1 a / 2$ & 5'-UTR \\
\hline AA439338 & LD13879 & Embryo & $1 \mathrm{a} / 2$ & $5^{\prime}$-UTR \\
\hline AI259128 & LP02469 & Larval-early pupal & $1 \mathrm{a} / 3$ & aa $1-150$ \\
\hline AA816374 & LD01314 & Embryo & $1 \mathrm{a} / 2$ & Exon 1a \\
\hline AI258551 & LP01773 & Larval-early pupal & la/unknown & Exon 1a \\
\hline AI515398 & LD47212 & Embryo & $1 \mathrm{a} / 3$ & Exon 1a \\
\hline AI514989 & LD46642 & Embryo & $1 \mathrm{a} / 2$ & Exon 1a \\
\hline AI542017 & SD08040 & Schneider L2 cells & $1 \mathrm{a} / 2$ & Exon 1a \\
\hline
\end{tabular}

Drosophila EST clones possessing novel sequence were identified in a series of search routines of the dbEST using the $5^{\prime}$-untranslated region (UTR) of stat92E, the sequence encoding amino acids (aa) 1-150 of STAT92E, and the novel sequence termed Exon 1a, as the input data.

$4 \mathrm{~A}$, lanes 3 and 4 contain the $+\mathrm{RT}$ and $-\mathrm{RT}$ reactions using primers for Drosophila GAPDH, showing that the mRNA was not contaminated with genomic DNA. The RT-PCR products were further amplified in a standard PCR reaction (Fig. 4B) to generate sufficient material for DNA sequencing, which confirmed that in the 734-bp product Exon 1a is spliced to Exon 3, and in the 1047-bp product Exon 1a is spliced to Exon 2.

Because mRNAs containing Exons 1 then 2, 1a then 2, and 1a then 3 had been identified, it seemed that two overlapping transcription units (beginning with either Exon 1 or 1a) existed in the stat92E locus. Therefore, we determined the start sites of the RNA transcripts using 5 '-RACE (rapid amplification of $\underline{c}$ DNA ends) assays and DNA sequencing of several of the cDNA clones. In this
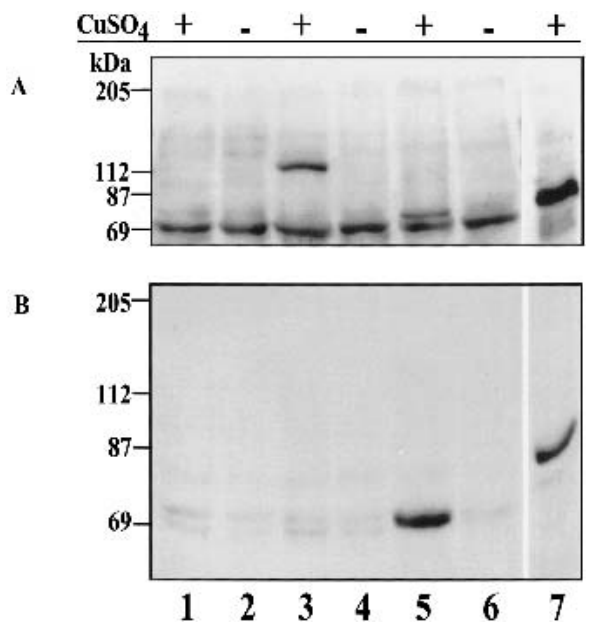

Figure 3. Expression of $\triangle$ NSTAT92E from clone LP02469. (A) The Western blot was probed with anti-His antibody. Cells were induced or uninduced (+ or - ) with copper sulfate. Untransfected S2 cells (lanes 1,2); S2 cells transfected with pMT/V5-His/lacZ (lanes 3,4); S2 cells transfected with pMT/V5-His/DNSTAT92E (lanes 5,6); and S2 cells transfected with pMT/V5-His/ STAT92E-TAD (lane 7). (B) The blot was probed with $\alpha$-CC serum. The lanes are the same as in $A$. Tagged $\triangle$ NSTAT92E, 73 $\mathrm{kD}$; tagged $\beta$-galactosidase, $119 \mathrm{kD}$; tagged STAT92E-TAD, $82 \mathrm{kD}$. manner we identified two different initiator sites (Fig. 5), proving the alternative use of two promoters. The first promoter possesses a potential TATA-box sequence at position -26. Although promoter 1a does not have a TATA-box sequence, its initiator site is followed by a downstream promoter element (DPE) at +28 (Burke and Kadonaga 1996, 1997). Promoter 1a has a C at +14 and a $\mathrm{G}$ at position +24 , which increase DPE promoter activity (Kutach and Kadonaga 2000). Downstream promoter elements are found in $\sim 30 \%-40 \%$ of Drosophila promoters (Kutach and Kadonaga 2000) and are postulated to be functional counterparts to the TATA box.

Therefore, alternative promoter usage defines the $5^{\prime}$ end of two mRNAs that encode $86-\mathrm{kD}$ protein STAT92E and allows for differential splicing from transcripts originating from promoter $1 \mathrm{~A}$ to generate the shorter form, $\triangle$ NSTAT92E (summarized in Fig. 6). We could find no evidence, by either RACE-PCR or by searching the EST database, of cDNAs wherein Exon 1 is alternatively spliced to Exon 3. Transcription from the two different promoters, 1 and $1 \mathrm{a}$, may well be regulated differently based on the differences in their sequences.

\section{Distribution of stat92E mRNAs during development}

To determine whether the steady-state concentration of mRNAs transcribed from the two stat92E promoters changes throughout development, we first performed Northern blots on RNA extracted from different stages (Fig. 7). A probe (Exons 3 and 4) that reacted with all mRNAs (Fig. 7A) showed a large amount of maternal stat92E mRNA (Fig. 7A, 0-1-h lane) and decreasing amounts of mRNA later in embryogenesis, with stronger expression returning in third-instar larvae and adults. This same picture was mirrored in the mRNA that arises from promoter 1a (Fig. 7C). The later embryonic increase was not as prominent in mRNA arising from promoter 1 (Fig. 7B). Quantitative RT-PCR (Fig. 7D) to distinguish promoter 1a mRNAs encoding full-length or shorter protein revealed that the $\Delta$ Nstat $92 E$ mRNA was largely responsible for the strong signal in larval and adult samples. These results are consistent with the protein expression shown in Figure 1, where $\triangle$ NSTAT92E predominates in first-instar larvae. Furthermore, the exis- 
$\mathbf{A}$

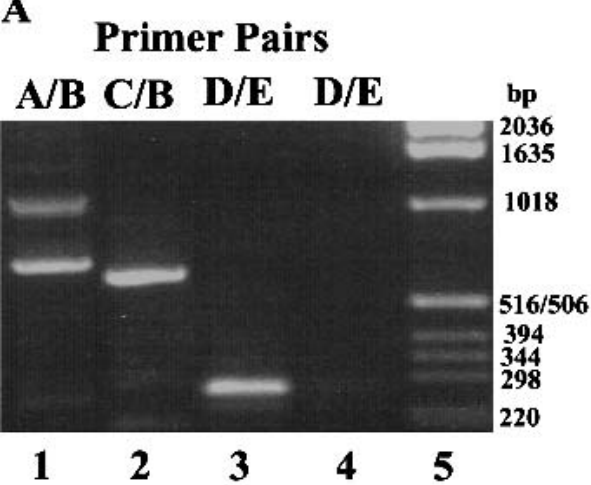

B

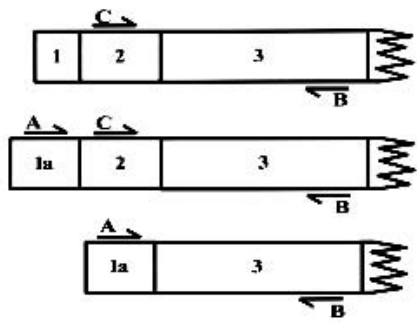

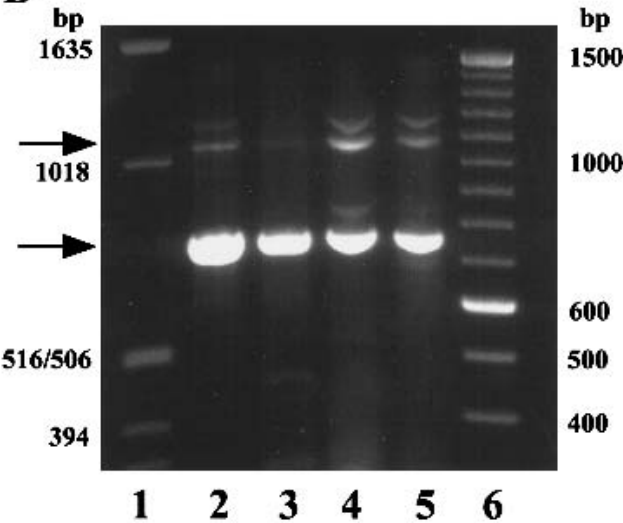

Figure 4. RT-PCR of S2 cell, Drosophila embryo, larva, and adult RNA. (A) 1.5\% agarose/TBE gel of RT-PCR reactions for embryo RNA. The primer locations are indicated. Primers D and E are to the Drosophila GAPDH sequence; (lane 4) the cDNA ${ }^{-}$reaction; (lane 5) 1-kb DNA ladder. Similar results were seen for larvae, adult fly, and S2 cell RNA. (B) Shows $1.5 \%$ agarose/TBE gel of PCR reactions performed on the RT-PCR reactions of primer pair A/B; (lane 1) 1-kb DNA ladder; (lane 2) S2 cell; (lane 3) larva; (lane 4) embryo; (lane 5) adult; (lane 6) 100-bp DNA ladder. The arrows indicate the bands that were gel-purified and directly sequenced.

tence is indicated of a regulated alternative splicing mechanism for transcripts arising from promoter 1a, opening the possibility for different functions for the full-length STAT92E protein compared with the shorter $\Delta$ NSTAT92E protein.

\section{Expression of $\Delta$ NSTAT92E results in suppression of STAT signaling}

We next tested the developmental effects of changing the ratio of STAT92E to $\triangle$ NSTAT92E in embryogenesis by

A

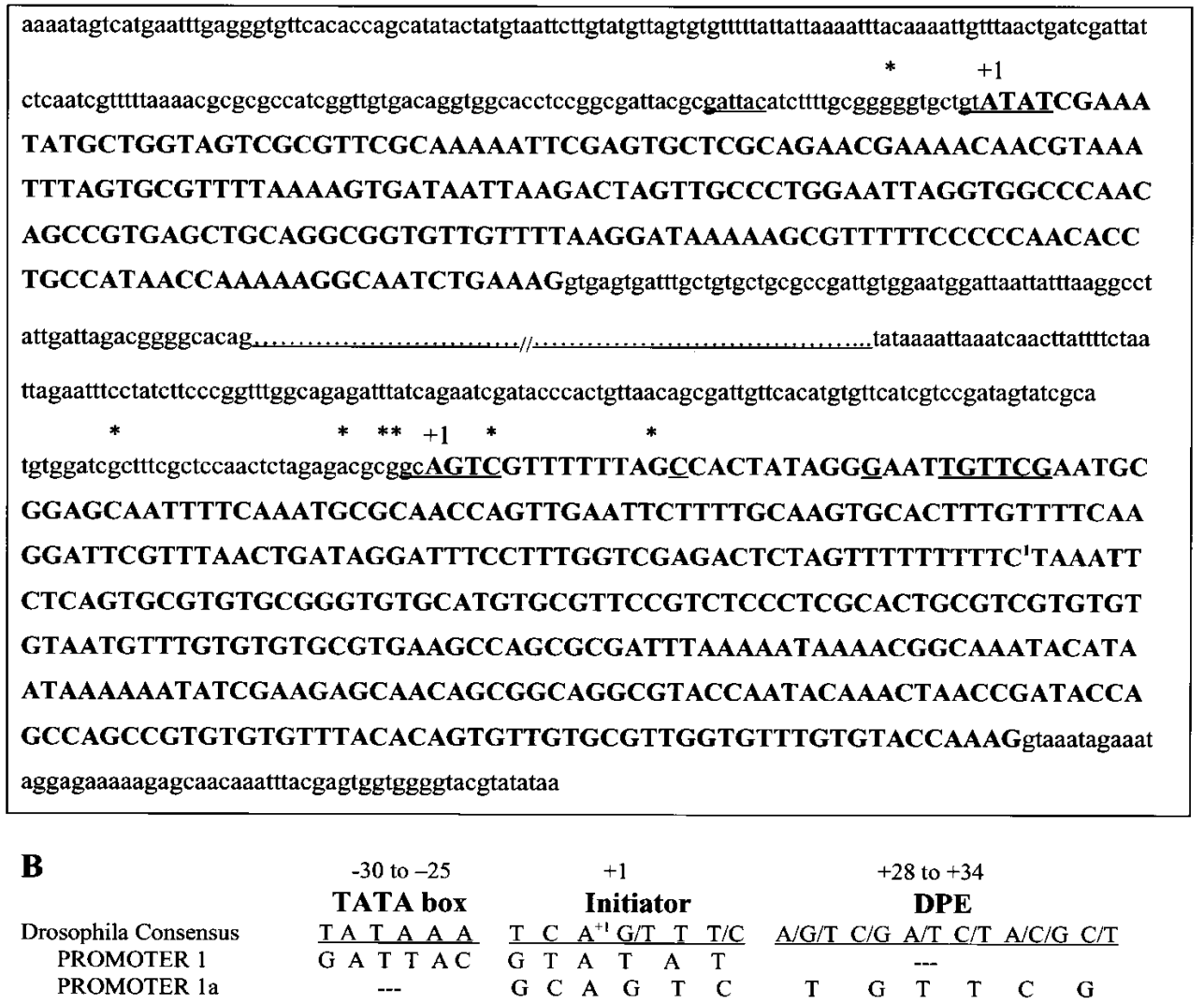

Figure 5. Two stat92E Promoters. (A) The transcription start sites are labeled $+1(>60 \%$ of the RACE-PCR clones started at these sites). Asterisks indicate the $5^{\prime}$ - ends of other clones. The two highlighted exons are separated by 975 bp in the genomic sequence. A potential TATA box, an initiator, and a downstream promoter element are underlined. $(B)$ Diagram showing the proper spacing between these elements and their Drosophila consensus sequences. 


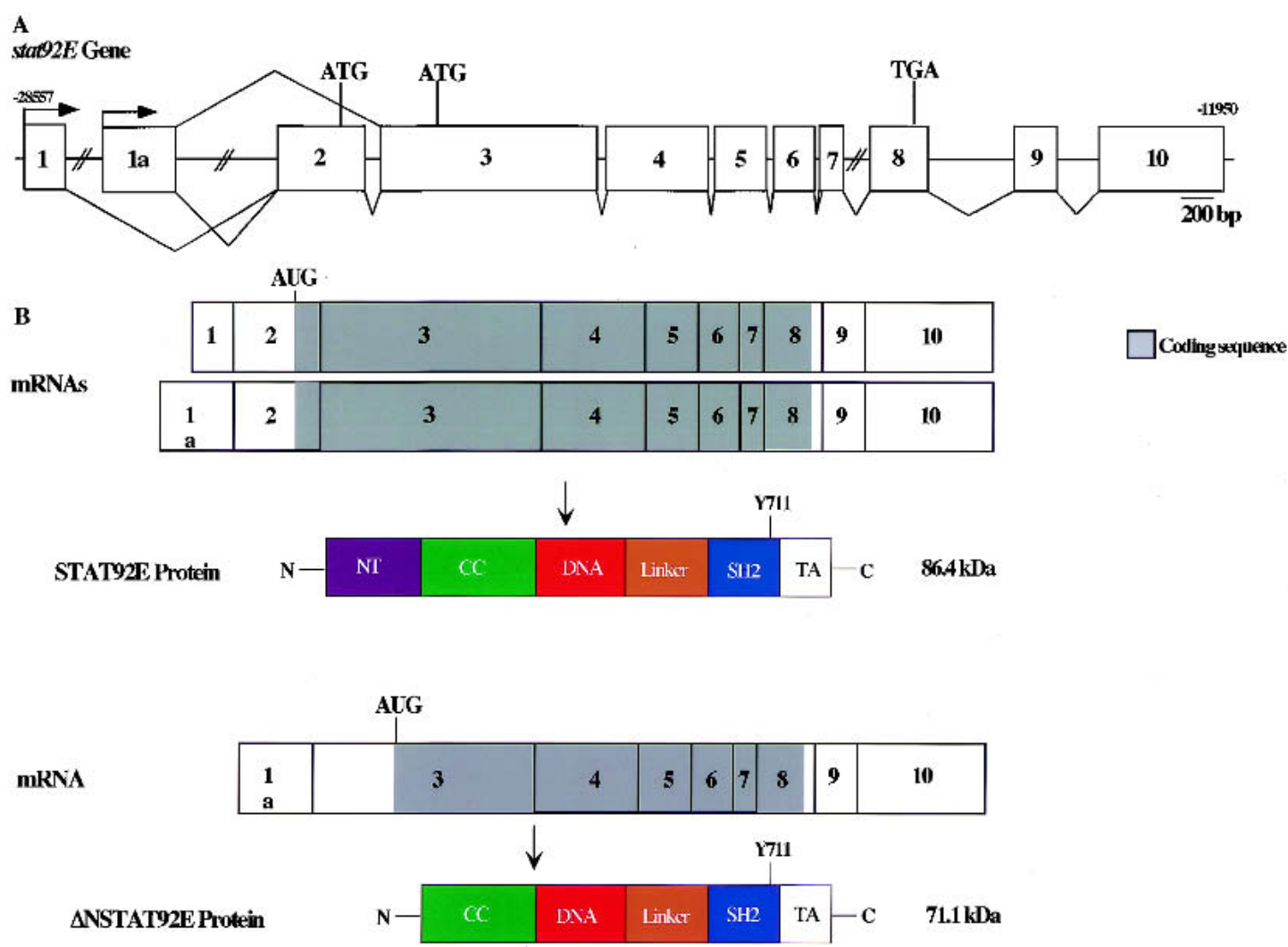

Figure 6. Gene, mRNA transcript, and protein structures of STAT92E. (A) Diagram of the exon structure of the stat92E gene. Exon $1 \mathrm{a}$ is $975 \mathrm{bp}$ downstream of Exon 1 and $8.6 \mathrm{~kb}$ upstream of Exon 2 in the Drosophila genome (GenBank accession no. AE003731). Exons 7 and 8 are $1.8 \mathrm{~kb}$ apart. When aligned with the stat92E cDNA, the last exon identified by Adams et al. (2000) is split into two exons (Exons 9 and 10 here). (B) Three mRNA transcripts identified for stat92E. The first is the original stat92E message, which is transcribed starting at the upstream promoter, where the start codon AUG appears in the last third of Exon 2 and a full-length protein of $86 \mathrm{kD}$ is translated. The seven-residue insert after residue 698 occurs via a differential splice between Exons 6 and 7 (Michael Melnick, pers. comm.). These two mRNAs are not distinguished here. The second message is the alternative start-site transcript, where Exon 1a precedes Exon 2 and the same start codon is used. The third is a splicing variant of this transcript, where Exon 1a is spliced to Exon 3 and a second start codon is used, truncating the $\mathrm{N}$-terminal domain. The domain structure predicted for STAT92E is by analogy to the X-ray crystal structures of mammalian Stat1 and Stat3 (Becker et al. 1998; Chen et al. 1998).

overexpressing $\triangle$ NSTAT92E. The pair-rule gene evenskipped (eve) is expressed in seven stripes along the anterior/posterior axis of the 2-3-hour-old embryo. The expression pattern is under the control of modular enhancers that integrate spatial information of localized transcription factors to produce the seven-stripe pattern (Small et al. 1996). For instance, in loss-of-function (LOF) mutants of stat92E and hopscotch (the Drosophila JAK), eve stripes, most commonly stripes 3,5 , and 7 , are variably reduced, whereas stripes 1 and 2 are usually unaffected (Binari and Perrimon 1994; Hou et al. 1996; Yan et al. 1996b). That activation of stripe 3 and 7 is the direct consequence of STAT92E binding to two neighboring STAT DNA-binding sites contained in the eve stripe $3+7$ enhancer $(3.5 \mathrm{~kb}$ upstream of the transcription start site) was shown by point mutagenesis and reporter gene assays in embryos (Yan et al. 1996b). Therefore, if $\triangle$ NSTAT92E had a dominant-negative function, overexpression would be expected to suppress production of EVE protein at STAT92E-dependent stripes but not at other eve stripes.
We used the binary UAS-Gal4 expression system for conditional overexpression of $\triangle$ NSTAT92E early in embryonal development (Brand et al. 1994). This system takes advantage of the ability of the yeast transcriptional activator GAL4 to function in Drosophila cells (Fischer et al. 1988). Drosophila strains that express GAL4 specifically at one stage of development or in a specific cell type can be mated to strains carrying a GAL4-responsive transgene that expresses any gene of interest. We chose NGT-Gal4 (nanos-GAL4-tubulin), which has been used to express GAL4 early in development during stripe formation of other pair-rule genes (Tracey et al. 2000). We assayed EVE expression with an anti-EVE antibody in stocks carrying both a Gal4-responsive UAS- $\Delta$ Nstat $92 E$ transgene and NGT-Gal4 (Fig. 8). For comparison, we included a stat $92 E^{397}$ embryo (Fig. 8C) defective in STAT function because of a truncation at the SH2 domain (Silver and Montell 2001). We found that EVE production of stripes 3,5 , and 7 was variably reduced in $20 \%-40 \%$ of the embryos overexpressing $\triangle$ NSTAT92E (Fig. 8B). Control embryos with only NGT-GAL4 (Fig. 8A) or embryos 


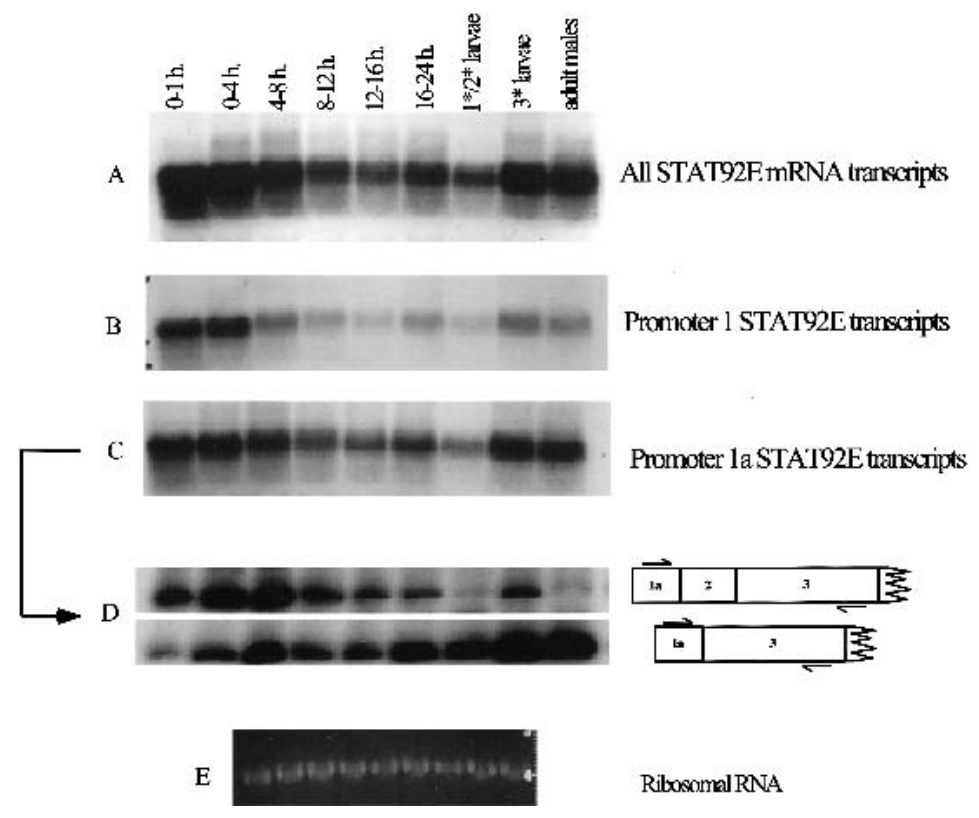

Figure 7. Staged Northern blot and RT-PCR. Total RNA was collected at various times during embryogenesis, from first- and second-instar larvae together, from third-instar larvae, and from adult males. $(A)$ Probe specific for Exons 3 and 4. (B) Probe specific for Exon 1. (C) Probe specific for Exon 1a. (D) Quantitative RT-PCR to amplify the alternatively spliced transcripts from promoter 1a. Primer locations are indicated. $(E)$ Ethidiumbromide-stained ribosomal RNA indicates loading of total RNA in each lane. overexpressing STAT92E (data not shown) displayed a wild-type seven-stripe pattern. In addition, as was previously shown for other STAT pathway mutants (Yan et al. $1996 \mathrm{~b})$, the stat92 $E^{397}$ embryos show reduction of stripe 3 and poor spreading so that stripe count was not possible. Taken together, these experiments suggest that $\triangle$ NSTAT92E can suppress transcriptional activation by STAT92E in vivo.

\section{RNA interference}

To remove specific forms of STAT92E for comparison with the overexpression results, RNAi experiments (Kennerdell and Carthew 1998; Clemens et al. 2000) involving dsSTAT-encoding sequences were performed. Prior to injecting dsRNAs (double-strand RNAs) corresponding to Exon 2 or Exons 3 and 4 into embryos, their efficacy in decreasing various stat $92 E \mathrm{mRNAs}$ was characterized by RT-PCR in S2 cells in culture. dsRNA corresponding to Exons 3 and 4 reduced all stat92E mRNA and proteins, whereas dsRNA corresponding to Exon 2 specifically reduced the $\Delta$ Nstat $92 E$ mRNA and protein with equal efficacy (Supplemental Fig. 1, in Supplementary Material at http://www.genesdev.org). Unfortunately, there is no exon combination that would leave stat92E mRNA unaffected and remove only the $\Delta$ Nstat92E mRNA.

The JAK-STAT pathway not only affects stripe formation but also embryonic segmentation (Luo and Dearholf 2001), and defects in segmentation were used to score the effect of the injection of dsRNAs. Loss of maternal hopscotch, domeless (the pathway receptor), or stat92E activity often results in the deletion of the fourth and fifth abdominal segments, observed in cuticle preparations. Null embryos lacking both maternal and paternal contributions from these genes can have additional de-
A

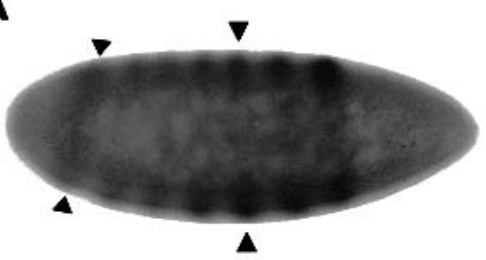

B
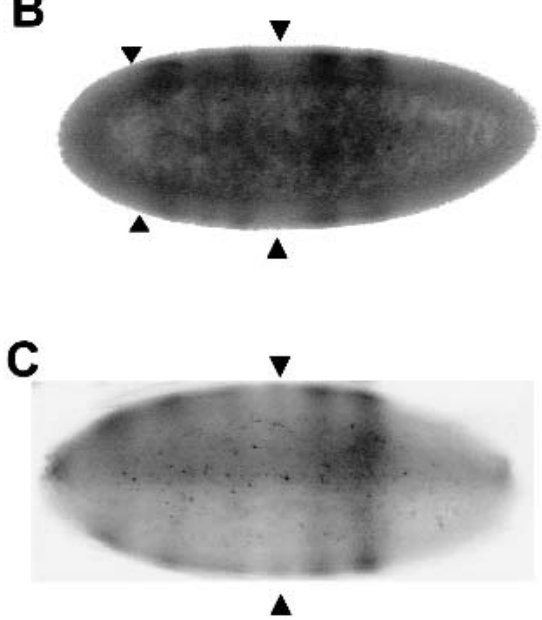

Figure 8. Overexpression of $\triangle$ NSTAT92E in 1-5-h old embryos suppresses activation of the STAT92E-dependent eve stripes 3, 5, and 7. (A) Seven eve stripes can be observed in NGT-Gal4 embryos representing the wild-type pattern. (B) In UAS-DNstat92E; NGT-Gal4 embryos, stripes 3 and 7 are clearly suppressed and stripe 5 to some degree. The position of the missing stripes 3 and 7 is marked by arrowheads. $(C)$ stat92E ${ }^{397}$ germ-line clone (Silver and Montell 2001) with a strongly suppressed stripe 3 and poor spreading of other stripes. The anterior is to the right. 
fects in the head and tail region (Hou et al. 1996; Yan et al. 1996b).

When embryos (0-1 h) were injected with ds-Exon3/4 RNA (Fig. 9B), which should lower the concentration of all possible stat92E mRNA, 7 of 103 surviving larvae had a loss and/or fusion of abdominal segments four and five. No defects in head or tail segments were seen. (Injection of buffer alone caused no defects in 105 animals.) Other embryos were injected with ds-Exon2 RNA (Fig. 9C), which would not affect the amount of $\Delta$ Nstat92E mRNA but would decrease all the mRNA encoding full-length protein regardless of which promoter was used. In the surviving larvae, 16 of 153 had fused segments four and five, and defects in the head and tail were also observed in another 12 of the 153. Upon translation of the maternally deposited mRNA (plus any new mRNA synthesized very early in embryogenesis), these latter injected embryos would have a higher ratio of $\triangle$ NSTAT92E protein compared with full-length protein. That the more severe defective phenotype is seen in embryos where the ratio of $\Delta$ NSTAT92E-protein-to-full-length protein was increased shows that $\triangle$ NSTAT92E acts negatively. In contrast, when all the stat92E mRNAs are depleted, only the less severe defect is seen.

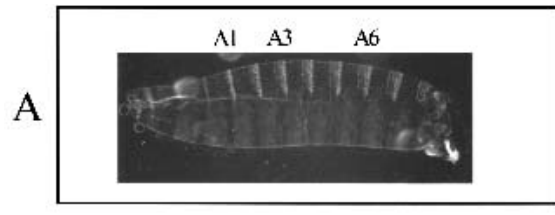

wild type embryo

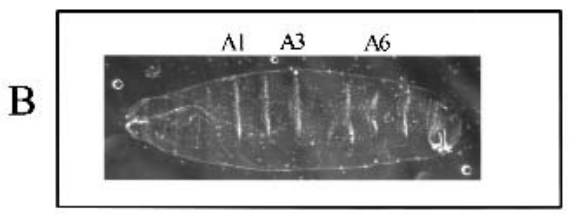

ds-exon 3/4 RNA

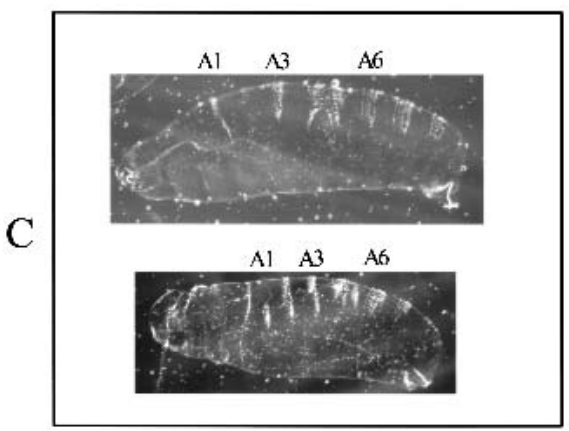

ds-exon 2 RNA

Figure 9. RNA interference of stat $92 E$ activity in embryos. Cuticle preparations of embryos. (A) Wild-type embryo (buffer injection; 105 of 105), with abdominal segments 1,3 , and 6 labeled. $(B)$ Injection of $5 \mu \mathrm{M}$ ds-Exon3/4 RNA. The abdominal segments 4 and 5 are missing or fused (7 of 103). This phenotype is similar to paternally rescued hopscotch, stat92E, and domeless null embryos. $(C)$ Injection of $5 \mu \mathrm{M}$ ds-Exon2 RNA. Some embryos had the phenotype involving the abdominal segments 4 and 5 (16 of 153), whereas some had additional more severe segmentation defects involving the head and tail region (12 of 153). This phenotype is similar to parternally unrescued hopscotch, stat92E, and domeless null embryos. The images were scaled identically. Anterior is to the left.

\section{Discussion}

There are only seven STATs in mammals, whereas the proteins are activated by a very wide array of extracellular signaling proteins affecting events in a wide variety of cells. Even in Drosophila, where there is a single STAT gene, the pathway affects many different developmental events. This situation repeatedly raises the question of how specificity of cell responses is brought about.

The findings in the present work bear directly on the question of how a single gene or a limited set of genes affects a large number of pathways. The differential activity of negative-acting proteins (SOCS, PIAS, phosphatases) can obviously affect the duration and strength of a STAT gene activation. To this list of negative-acting proteins we can now add, at least in Drosophila, omission of the N-terminal STAT domain. Furthermore, differential appearance of functional forms of STAT92E in different cell types during development is possible with $\Delta$ NSTAT92E acting as a negative regulator of the fulllength protein. This shorter protein could, as is the case in mammals, fail to activate genes as well as wild-type protein by failing to attract coactivators, for example, CBP/p300 (Zhang et al. 1996), or by failing to form tetramers when two STAT binding sites for dimers are close together (Xu et al. 1996; Vinkemeier et al. 1998). It is interaction between the $\mathrm{N}$-terminal domains that allows tetramer formation, which is required in the activation of certain genes (Guyer et al. 1995; John et al. 1999).

The regulation of transcription from the two different promoters is obviously a possibility for controlling the effects of the full-length STAT protein. Use of only promoter 1 would produce only full-length protein. Transcription from promoter la would produce both fulllength STAT92E and $\Delta$ NSTAT92E protein. Furthermore, in processing primary transcripts from promoter $1 \mathrm{a}$, a choice of splice sites to include or exclude Exon 2 can occur. These choices are used, because the amount of stat $92 E$ and $\Delta$ Nstat92E mRNA changes throughout development.

Overlapping transcription units were first discovered in the rat $\alpha$-amylase gene, $A m y$ - $1 a$, where two different start sites produced liver or salivary gland mRNAs at vastly different rates but encoding the same protein (Schibler et al. 1983). Tissue-specific variation in start sites with resulting quantitative differences in protein formation has been described many times since, but in the case we describe here the utilization of the Exon 1a start site could have the effect of negatively regulating any protein arising from transcription using promoter 1 , a situation most analogous to that described for the human CCAAT/enhancer-binding protein $\varepsilon(C / E B P \varepsilon)$ gene (Yamanaka et al. 1997). Alternative use of two promoters combined with differential splicing yields four C/EBP $\varepsilon$ mRNA isoforms, which in turn generate three proteins that differ in their $\mathrm{N}$ termini, with different transactivating properties.

Finally, the present findings in Drosophila suggest the possibility in mammalian cells of tissue-specific tran- 
scription initiation sites and variations in $\mathrm{N}$-terminal protein sequences of the STATs. It seems unlikely that such potentially valuable variations in gene regulation would be discarded in evolution.

\section{Materials and methods}

\section{Cell culture}

Schneider 2 (S2) cells were maintained in Shields and Sang M3 Insect Media (Sigma) supplemented with $10 \%$ heat-inactivated fetal bovine serum (Gemini Bio-Products) at $25^{\circ} \mathrm{C}$.

\section{Plasmids}

Drosophila cDNA clones from the Berkeley Drosophila Genome Project were purchased from Research Genetics. DNA sequencing was performed at the Rockefeller University Protein DNA Technology Center. The cDNA from clone LP02469 was amplified by PCR using Vent polymerase (New England BioLabs) with primers annealing to the multiple cloning site of the pOT2a vector just upstream of the EcoRI site and to the C terminus of STAT92E, but with a stop-codon mutation to allow for histidine tagging. The PCR product was subcloned into the NotI site of pMT/V5-His C (Invitrogen). The insert of the LP02469 pMT/V5-His C plasmid was sequenced entirely, and a $\mathrm{G} \rightarrow \mathrm{T}$ point mutation was discovered that resulted in an Ochre termination signal. The same mutation was found in the original LP02469 cDNA clone. The point mutation was repaired using the QuikChange Mutagenesis Kit (Stratagene). The control expression vector $\mathrm{pMT} / \mathrm{V} 5-\mathrm{His} / \mathrm{lacZ}$ was from Invitrogen, and $\mathrm{pMT} / \mathrm{V} 5$-His/STAT92E-TAD was prepared from the original stat92E cDNA by PCR-based subcloning into the EcoRI and $\mathrm{XbaI}$ sites of $\mathrm{pMT} / \mathrm{V} 5$-His A such that the putative transactivation domain was removed (residues 694-754).

\section{STAT92E antibody production}

Two PCR fragments were generated corresponding to amino acids $1-134$ and amino acids $135-338$, the putative $\mathrm{N}$-terminal and coiled-coil domains of STAT92E, with the forward primer containing an EcoRI site and the reverse primer an NotI site. Both fragments were cloned into the pGEX vector (Stratagene) to create glutathione $S$-transferase (GST) fusion proteins. The resulting clones were sequenced, and protein was expressed according to the manufacturer's protocol. The protein was purified on glutathione-coupled beads and injected into rats nine times at 4-wk intervals (Covance). In the first four injections, $100 \mu \mathrm{g}$ of protein was injected, and in the later injections $50 \mu \mathrm{g}$ per injection was used. The sera from the third bleed onward were tested on Western blots and in EMSA supershifts.

\section{Western blots}

Extracts were prepared from S2 cells, embryos, or larvae according to Betz et al. (2001). The Flag-tagged STAT92E construct and antibody used are described in Yan et al. (1996b). Protein concentrations were measured using the Bio-Rad protein assay, and $15 \mu \mathrm{g}$ of total protein per lane was subjected to SDS-PAGE and immunoblotted using standard methods. Anti-STAT92E amino acids $1-134$ of the $\mathrm{N}$-terminal domain $(\alpha-\mathrm{NT})$ and antiSTAT92E amino acids $135-338$ of the coiled-coil domain $(\alpha-\mathrm{CC})$ were used at a 1:10,000 and 1:20,000 dilution, respectively, in 5\% non-fat milk dissolved in Tris-buffered saline containing Tween20 (TBST). An anti-rat horseradish peroxidase (HRP) antibody (Jackson ImmunoResearch Laboratory) was used as the secondary antibody at the recommended concentration. The blots were developed with Renaissance chemiluminescence reagent (NEN).

\section{EMSA}

Electrophoretic mobility shift assays (EMSAs) were performed as previously described (Vinkemeier et al. 1996). The protocol was adapted for Drosophila embryos and larvae, and the signalto-noise ratio was improved by the following modifications: staged Drosophila embryos were grown and collected from apple juice agar plates $20 \%$ agar, $3.3 \%$ sucrose, $25 \%$ apple juice), dechorionated for $2 \mathrm{~min}$ in $50 \%$ bleach, washed with PBS, and homogenized in low salt extraction buffer (Yan et al. 1996b) in 1.75-mL Eppendorf tubes using a minipestle (Kontes). After centrifugation the pellet was resuspended in high-salt nuclear extraction buffer and incubated on ice for $30 \mathrm{~min}$. The samples were microfuged for $5 \mathrm{~min}$, and $2 \mu \mathrm{L}$ of the supernatant was used in the EMSA. The probe was described in Yan et al. (1996b). Alternatively, the nuclear extract of 1-5-h embryos and larvae was concentrated $\sim 10$-fold in spin columns (Microcon 3000) before being applied to the EMSAs.

\section{Fly stocks and crosses}

To select stat $92 E^{06346}$ homozygous first-instar larvae, a stock was created that allowed for selection by the absence of the larval marker, actin green fluorescence protein (Act-GFP) located on the TM3 balancer chromosome. To this end, Sb/TM3, Act-GFP (B\#4534) was crossed to stat $92 E^{06346} / T M 3$ (B\#1681), a lethal $P$-element insertion line. stat $92 E^{06346} / T M 3$, Act-GFP larvae were selected, the $F_{1}$ generation was selfed, and a stock was established. stat $92 E^{06346}$ homozygous larvae were identified by selecting colorless larvae under a dissecting microscope equipped with a fluorescent light source. Larvae of this stock were grown on apple juice/agar plates, and 24-36-h first-instar larvae were collected according to the absence of GFP using a Leica dissecting microscope with a green light source. Wild-type (Oregon R) flies were grown and selected in parallel. All stocks were from Bloomington, Indiana. The NGT line was kindly provided by J. Peter Gergen (State University of New York at Stony Brook, Stony Brook, NY). Four independent transgenic lines carrying UAS- $\Delta$ Nstat $92 E$ were generated by P-elementmediated transformation. stat $92 E^{397}$ flies were kindly provided by the Montell lab (Silver and Montell 2001). Adults of a transgenic hs-stat92E stock expressing only full-length STAT92E were heat-shocked daily, and embryos were collected. EVE stripes in these embryos were wild type. That this stock actually expresses STAT92E is indicated by the fact that it can partially rescue the viability of stat $92 E^{06346}$ homozygotes (data not shown) and also rescues the wing vein abnormality of stat ${ }^{H J}$ mutants (Yan et al. 1996a).

\section{BLAST sequence similarity searches}

Clones possessing novel sequence were identified in a series of search routines of the National Center for Biotechnology Information (NCBI) expressed sequence tagged database (dbEST) using the $5^{\prime}$-untranslated region (5'-UTR) of stat $92 E$, the sequence encoding amino acids 1-150 of STAT92E, and the novel sequence termed exon 1a, as the input data (Altschul et al. 1990). The relative positions of Exons 1, 1a, and 2 in the genomic sequence were determined by a BLAST sequence similarity search of the NCBI Drosophila genome (Adams et al. 2000).

\section{Expression of $\triangle N S T A T 92 E$}

Transient transfections were performed with the GIBCO-BRL Calcium Phosphate Transfection Kit. Recombinant protein expression was according to the Drosophila Expression System protocol (Invitrogen). Then $30 \mu \mathrm{g}$ of total protein was subjected to SDS-PAGE and immunoblotted using standard methods. 
The expression of $\triangle$ NSTAT92E and the control, $\beta$-galactosidase, was confirmed using monoclonal Anti-His (C-term) Antibody (Invitrogen) at a 1:5000 dilution in 1\% bovine serum albumin (BSA) dissolved in TBST. The secondary antibody, peroxidase-conjugated AffiniPure Goat Anti-Mouse IgG (Jackson ImmunoResearch Laboratories), was used at the same dilution. The blot was developed with Renaissance chemiluminescence reagent (NEN). A second gel was immunoblotted and probed with the $\alpha$-CC antibody as described above.

\section{$R T-P C R$ and $5^{\prime}-R A C E-P C R$}

Poly(A) ${ }^{+}$RNA (20 ng) from Drosophila embryo, larvae, or adult (Clontech) was used with the ProSTAR HF Single-Tube RTPCR System (Stratagene) to amplify stat92E mRNA possessing Exon 1a. The cDNA synthesis was performed at $42^{\circ} \mathrm{C}$ for $1 \mathrm{~h}$, and the annealing temperature was lowered to $50^{\circ} \mathrm{C}$. Primer pairs are indicated in Figure 4. Forward primer A, $5^{\prime}$-CAAAT GCGCAACCAGTTGAATTC-3'; reverse primer B, 5'-GGCAA TGCCTGTATTTTGCACA-3'; forward primer C, 5'-TCC GAGCCAGAATCAGAAACAC-3'; forward primer D, 5' -ACC GTCGACGGTCCCTCT-3'; reverse primer E, 5'-GTGTAGC CCAGGATTCCCT-3'. Total RNA from S2 cells was isolated using TRIzol Reagent (GIBCO-BRL), and the RT-PCR was performed as previously described without the use of radioactivity (Yang et al. 1999). Then $10 \%$ of the RT-PCR reactions was run on a $1.5 \%$ agarose/TBE gel. To improve the specificity and further amplify the products for direct sequencing, $1 \mu \mathrm{L}$ of each of the four Primer A/B RT-PCR reactions was subjected to standard PCR (anneal at $52^{\circ} \mathrm{C}$ ) and run on a preparative $1.5 \%$ agarose/TBE gel. The indicated bands were gel-purified and sequenced. The PCR reactions were not performed under quantitative conditions (i.e., low number of cycles); therefore, no interpretation as to the relative amounts of mRNA where Exon $1 \mathrm{a}$ is spliced to Exon 2 versus to Exon 3 can be made. To identify the 5'-ends for the S2 and embryo RNA transcripts, Clontech's SMART RACE cDNA amplification kit was used as directed by the manufacturer's protocol. The stat $92 E$ specific primers from Exon 1a, 5'-CACACACGGCTGGCTGGTATCGG-3'; Exon 2, 5'-CAAGCTCATGCTCTTGCTCTACCCG-3'; and Exon 3, 5' GCGTGTACAGCTCAACGGCGGAG-3', were used in Touchdown PCR, and the various products were gel-purified and subcloned into pCR2.1 vector (Invitrogen) to generate clones for sequencing. In all, 45 clones were sequenced.

\section{Northern blotting}

Total RNA from different stages of Drosophila was extracted using RNeasy (QIAGEN). Each lane contained $10 \mu \mathrm{g}$ of total RNA separated and blotted (Hybond-N, Amersham) using standard procedures. Probes were radiolabeled using Prime-It RmT kit (Stratagene). The blot was hybridized $\left(1 \times 10^{6} \mathrm{cpm} / \mathrm{mL}, 1 \%\right.$ BSA Fraction V, 7\% SDS, $0.5 \mathrm{M} \mathrm{NaH}_{2} \mathrm{PO}_{4}$ at pH 7, $1 \mathrm{mM}$ EDTA at $\mathrm{pH} 8$ ) overnight at $68^{\circ} \mathrm{C}$, washed twice with $2 \times \mathrm{SSC}, 0.5 \%$ SDS at $56^{\circ} \mathrm{C}$ for $10 \mathrm{~min}$, then twice with $0.1 \times$ SSC, $0.1 \%$ SDS at $56^{\circ} \mathrm{C}$ for $30 \mathrm{~min}$. Stripping was performed using the latter wash buffer at $70^{\circ} \mathrm{C}$ for $2 \mathrm{~h}$. The quantitative RT-PCR reactions $(400$ ng of total RNA) shown were performed according to Yang et al. (1999) and run on a 5\% agarose gel in TBE buffer.

\section{Immunohistochemistry}

Embryos at $1-5 \mathrm{~h}$ were fixed and stained according to standard procedures. The stat $92 E^{397}$ stock was a gift of Denise Montell (Johns Hopkins School of Medicine, Baltimore, MD) and has the point mutation Trp594STOP. The anti-EVE antibody, kindly provided by David Kosman (New York University), was used at a 1:500 dilution. HRP-conjugated secondary antibody (Jackson
ImmunoResearch Labs) was used at a 1:1000 dilution. The HRP substrate was from Boehringer.

\section{$R N A i$}

RNAi in S2 cells was performed as described in Clemens et al. (2000). Cells were collected at $72 \mathrm{~h}$ for Western blotting or RTPCR to determine the efficacy of the dsRNAs used in embryo injections (Supplemental Fig. 1, in Supplementary Material at http://www.genesdev.org). Preparation of dsRNA, injections of $W^{-}$embryos, and cuticle analysis were performed as described in Kennerdell and Carthew (1998). ds-Exon2 RNA was prepared with T7-tagged primers, 5'-TTTCCTCCTTCTAACCATATTAA ATTC-3' and 5'-ATTATCCTGTCTTCGATCCA-3'. ds-Exon3/4 RNA was complementary to Exon 3 and a portion of Exon 4 and was prepared with T7-tagged primers 5'-GTCCGAACAAATA ACGCC-3' and 5'-ATAGGAAATCAAGGTTATCAAT-3'.

\section{Acknowledgments}

We thank Michael Melnick for providing the original genomic sequence of stat92E and Lois Cousseau for preparing the manuscript. We also thank Mike Young and Ulrike Gaul and their lab members for technical advice and sharing fly-related material and equipment. We thank Peter Gergen for providing the NGTGAL4 stock; Denise Montell for the stat $92 E^{397}$ stock; Charles Dearolf for the hs-STAT92E fly stock; and Steven Hou for antiSTAT92E antibody. M.A.H. was a Cancer Research Institute Postdoctoral Fellow. This work was supported by NIH grants AI32489 and AI34420 to J.E.D.

The publication costs of this article were defrayed in part by payment of page charges. This article must therefore be hereby marked "advertisement" in accordance with 18 USC section 1734 solely to indicate this fact.

\section{References}

Adams, M.D., Celniker, S.E., Holt, R.A., Evans, C.A., Gocayne, J.D., Amanatides, P.G., Scherer, S.E., Li, P.W., Hoskins, R.A., Galle, R.F., et al. 2000. The genome sequence of Drosophila melanogaster. Science 287: 2185-2195.

Altschul, S.F., Gish, W., Miller, W., Myers, E.W., and Lipman, D.J. 1990. Basic local alignment search tool. J. Mol. Biol. 215: 403-410.

Becker, S., Groner, B., and Muller, C.W. 1998. Three-dimensional structure of the Stat $3 \beta$ homodimer bound to DNA. Nature 394: 145-151.

Betz, A., Lampen, N., Martinek, S., Young, M., and Darnell, J.J. 2001. A Drosophila PIAS homologue negatively regulates stat92E. Proc. Natl. Acad. Sci. 98: 9563-9568.

Binari, R. and Perrimon, N. 1994. Stripe-specific regulation of pair-rule genes by hopscotch, a putative Jak family tyrosine kinase in Drosophila. Genes \& Dev. 8: 300-312.

Brand, A., Manoukian, A., and Perrimon, N. 1994. Ectopic expression in Drosophila. Methods Cell Biol. 44: 635-654.

Bromberg, J. and Darnell, J.J. 2000. The role of STATs in transcriptional control and their impact on cellular function. Oncogene 19: 2468-2473.

Burke, T.W. and Kadonaga, J.T. 1996. Drosophila TFIID binds to a conserved downstream basal promoter element that is present in many TATA-box-deficient promoters. Genes \& Dev. 10: 711-724.

- 1997. The downstream core promoter element, DPE, is conserved from Drosophila to humans and is recognized by TAFII60 of Drosophila. Genes \& Dev. 11: 3020-3031.

Carey, M. 1998. The enhanceosome and transcriptional synergy. Cell 92: 5-8.

Chen, X., Vinkemeier, U., Zhao, Y., Jeruzalmi, D., Darnell, J.E., 
Jr., and Kuriyan, J. 1998. Crystal structure of a tyrosine phosphorylated STAT-1 dimer bound to DNA. Cell 93: 827-839.

Clemens, J.C., Worby, C.A., Simonson-Leff, N., Muda, M., Maehama, T., Hemmings, B.A., and Dixon, J.E. 2000. Use of double-stranded RNA interference in Drosophila cell lines to dissect signal transduction pathways. Proc. Natl. Acad. Sci. 97: 6499-6503.

Darnell, J.E. 1997. Stats and gene regulation. Science 277: 16301635.

Darnell, J.E., Jr., Kerr, I.M., and Stark, G.R. 1994. Jak-STAT pathways and transcriptional activation in response to IFNs and other extracellular signaling proteins. Science 264: 1415-1421.

Fischer, J., Giniger, E., Maniatis, T., and Ptashne, M. 1988. GAL4 activates transcription in Drosophila. Nature 332: 853-856.

Guyer, N.B., Severns, C.W., Wong, P., Feghali, C.A., and Wright, T.M. 1995. IFN- $\gamma$ induces a p91/Stat la-related transcription factor with distinct activation and binding properties. J. Immunol. 155: 3472-3480.

Haspel, R. and Darnell, J.J. 1999. A nuclear protein tyrosine phosphatase is required for the inactivation of Stat1. Proc. Natl. Acad. Sci. 96: 10188-10193.

Hou, X.S., Melnick, M.B., and Perrimon, N. 1996. Marelle acts downstream of the Drosophila HOP/JAK kinase and encodes a protein similar to the mammalian STATs. Cell 84: 411-419.

John, S., Vinkemeier, U., Soldaini, E., Darnell, J.J., and Leonard, W. 1999. The significance of tetramerization in promoter recruitment by Stat5. Mol. Cell. Biol. 19: 1910-1918.

Kennerdell, J.R. and Carthew, R.W. 1998. Use of dsRNA-mediated genetic interference to demonstrate that frizzled and frizzled 2 act in the wingless pathway. Cell 95: 1017-1026.

Kozak, M. 1991. An analysis of vertebrate mRNA sequences: Intimations of translational control. J. Cell Biol. 115: 887-903.

Krebs, D.L. and Hilton, D.J. 2001. SOCS proteins: Negative regulators of cytokine signaling. Stem Cells 19: 378-387.

Kutach, A. and Kadonaga, J. 2000. The downstream promoter element DPE appears to be as widely used as the TATA box in Drosophila core promoters. Mol. Cell. Biol. 20: 4754-4764.

Levy, D. and Darnell, J.E., Jr. 2002. STATs: Transcriptional control and biologic impact. Nat. Rev. Mol. Cell Biol. (in press).

Look, D.C., Pelletier, M.R., Tidwell, R.M., Roswit, W.T., and Holtzman, M.J. 1995. Stat 1 depends on transcriptional synergy with Sp1. J. Biol. Chem. 270: 30264-30267.

Luo, H. and Dearholf, C. 2001. The JAK/STAT pathway and Drosophila development. Bioessays 23: 1138-1147.

Muller, M., Laxton, C., Briscoe, J., Schindler, C., Improta, T., Darnell, J.E., Jr., Stark, G.R., and Kerr, I.M. 1993. Complementation of a mutant cell line: Central role of the $91 \mathrm{kDa}$ polypeptide of ISGF3 in the interferon- $\alpha$ and $-\gamma$ signal transduction pathways. EMBO I. 12: 4221-4228.

Rubin, G., Hong, L., Brokstein, P., Evans-Holm, M., Frise, E., Stapleton, M., and Harvey, D. 2000. A Drosophila complementary DNA resource. Science 287: 2222-2224.

Schaefer, T.S., Sanders, L.K., and Nathans, D. 1995. Cooperative transcriptional activity of Jun and Stat $3 \beta$, a short form of Stat3. Proc. Nat1. Acad. Sci. 92: 9097-9101.

Schaefer, T.S., Sanders, L.K., Park, O.K., and Nathans, D. 1997. Functional differences between Stat $3 \alpha$ and Stat $3 \beta$. Mol. Cell. Biol. 17: 5307-5316.

Schibler, U., Hagenbuchle, O., Wellauer, P.K., and Pittet, A.C. 1983. Two promoters of different strengths control the transcription of the mouse $\alpha$-amylase gene Amy-1a in the parotid gland and the liver. Cell 33: 501-508.

Schindler, C., Fu, X.Y., Improta, T., Aebersold, R., and Darnell, J.E., Jr. 1992. Proteins of transcription factor ISGF-3: One gene encodes the 91- and $84-\mathrm{kDa}$ ISGF-3 proteins that are activated by interferon $\alpha$. Proc. Natl. Acad. Sci. 89: 7836-7839.

Shuai, K. 2000. Modulation of STAT signaling by STAT-interacting proteins. Oncogene 19: 2638-2644.

Silver, D.L. and Montell, D.J. 2001. Paracrine signaling through the JAK/STAT pathway activates invasive behavior of ovarian epithelial cells in Drosophila. Cell 107: 831-841.

Small, S., Blair, A., and Levine, M. 1996. Regulation of two pair-rule stripes by a single enhancer in the Drosophila embryo. Dev. Biol. 175: 314-324.

Stark, G., Kerr, I., Williams, B., Silverman, R., and Schreiber, R. 1998. How cells respond to interferons. Annu. Rev. Biochem. 67: 227-264.

Starr, R. and Hilton, D. 1999. Negative regulation of the JAK/ STAT pathway. Bioessays 21: 47-52.

Stocklin, E., Wissler, M., Gouilleux, F., and Groner, B. 1996. Functional interactions between Stat5 and the glucocorticoid receptor. Nature 383: 726-728.

ten Hoeve, J., Ibarra-Sanchez, M., Fu, Y., Zhu, W., Tremblay, M., David, M., and Shuai, K. 2002. Identification of a nuclear Statl protein tyrosine phosphatase. Mol. Cell. Biol. 22: 5662-5668.

Tracey, W.J., Ning, X., Klingler, M., Kramer, S., and Gergen, J. 2000. Quantitative analysis of gene function in the Drosophila embryo. Genetics 154: 273-284.

Vinkemeier, U., Cohen, S.L., Moarefi, I., Chait, B. T., Kuriyan, J., and Darnell, J.E., Jr. 1996. DNA binding of in vitro activated Stat $1 \alpha$, Stat $1 \beta$ and truncated Stat1: Interaction between $\mathrm{NH}_{2}$-terminal domains stabilizes binding of two dimers to tandem DNA sites. EMBO J. 15: 5616-5626.

Vinkemeier, U., Moarefi, I., Darnell, J.E., Jr., and Kuriyan, J. 1998. Structure of the amino-terminal protein interaction domain of STAT-4. Science 279: 1048-1052.

Wang, D., Stravopodis, D., Teglund, S., Kitazawa, J., and Ihle, J.N. 1996. Naturally occurring dominant negative variants of Stat5. Mol. Cell. Biol. 16: 6141-6148.

Xu, X., Ya-Lin, S., and Hoey, T. 1996. Cooperative DNA binding and sequence selective recognition conferred by the Stat amino terminal domain. Science 273: 794-797.

Yamanaka, R., Kim, G.D., Radomska, H.S., Lekstrom-Himes, J., Smith, L.T., Antonson, P., Tenen, D.G., and Xanthopoulos, K G. 1997. CCAAT/enhancer binding protein $\varepsilon$ is preferentially up-regulated during granulocytic differentiation and its functional versatility is determined by alternative use of promoters and differential splicing. Proc. Natl. Acad. Sci. 94: 6462-6467.

Yan, R., Lou, H., Darnell, J.E., Jr., and Dearolf, C.R. 1996a. A JAK-STAT pathway regulates wing vein formation in Drosophila. Proc. Natl. Acad. Sci. 93: 5842-5847.

Yan, R., Small, S., Desplan, C., Dearolf, C.R., and Darnell, J.E., Jr. 1996b. Identification of a Stat gene that functions in Drosophila development. Cell 84: 421-430.

Yang, E., Wen, Z., Haspel, R.L., Zhang, J.J., and Darnell, J.E., Jr. 1999. The linker domain of Stat 1 is required for $\gamma$ interferondriven transcription. Mol. Cell. Biol. 19: 5106-5112.

Yoo, J.Y., Huso, D.L., Nathans, D., and Desiderio, S. 2002. Specific ablation of STAT3 $\beta$ distorts the pattern of Stat3-responsive gene expression and impairs recovery from endotoxic shock. Cell 108: 331-344.

Zhang, J.J., Vinkemeier, U., Gu, W., Chakravarti, D., Horvath, C.M., and Darnell, J.E., Jr. 1996. Two contact regions between Stat 1 and $\mathrm{CBP} / \mathrm{p} 300$ in interferon $\gamma$ signaling. Proc. Natl. Acad. Sci. 93: 15092-15096.

Zhang, X., Wrzeszczynska, M.H., Horvath, C.M., and Darnell, J.E., Jr. 1999. Interacting regions in Stat3 and c-Jun that participate in cooperative transcriptional activation. Mol. Cell. Biol. 19: 7138-7146. 


\section{Corrigendum}

Genes \& Development 16: 2379-2389 (2002)

Negative regulation of STAT92E by an N-terminally truncated STAT protein derived from an alternative promoter site

Melissa A. Henriksen, Aurel Betz, Marc V. Fuccillo, and James E. Darnell, Jr.

In the Discussion we overlooked a report, of an N-terminally truncated form of human Stat6, that is relevant to our work. The reference is given below.

Patel, B.K., Pierce, J.H., and LaRochelle, W.J. 1998. Regulation of interleukin 4-mediated signaling by naturally occurring dominant negative and attenuated forms of human Stat6. Proc. Nat1. Acad. Sci. USA 95: 172-177. 


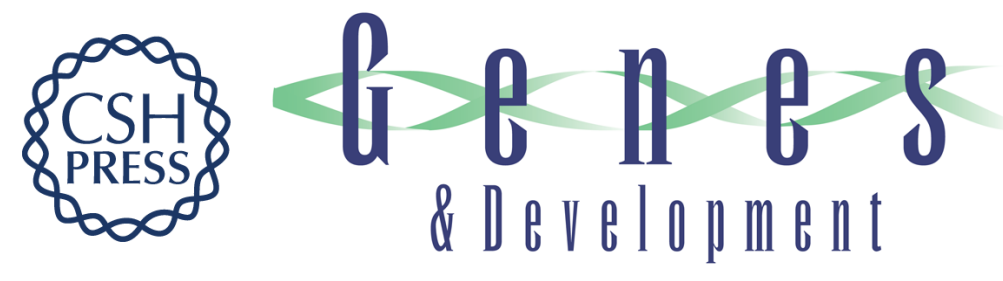

\section{Negative regulation of STAT92E by an N-terminally truncated STAT protein derived from an alternative promoter site}

Melissa A. Henriksen, Aurel Betz, Marc V. Fuccillo, et al.

Genes Dev. 2002, 16:

Access the most recent version at doi:10.1101/gad.1020702

\section{Supplemental http://genesdev.cshlp.org/content/suppl/2002/09/18/16.18.2379.DC1 \\ Material}

Related Content Errata for vol. 16, p. 2379

Genes Dev. October , 2002 16: 2729 STAT92E Cuts it Short and Keeps Things Quiet

Sci. STKE September, 2002 2002: tw349

References This article cites 50 articles, 28 of which can be accessed free at:

http://genesdev.cshlp.org/content/16/18/2379.full.html\#ref-list-1

Articles cited in:

http://genesdev.cshlp.org/content/16/18/2379.full.html\#related-urls

\section{License}

Email Alerting Receive free email alerts when new articles cite this article - sign up in the box at the top Service right corner of the article or click here.

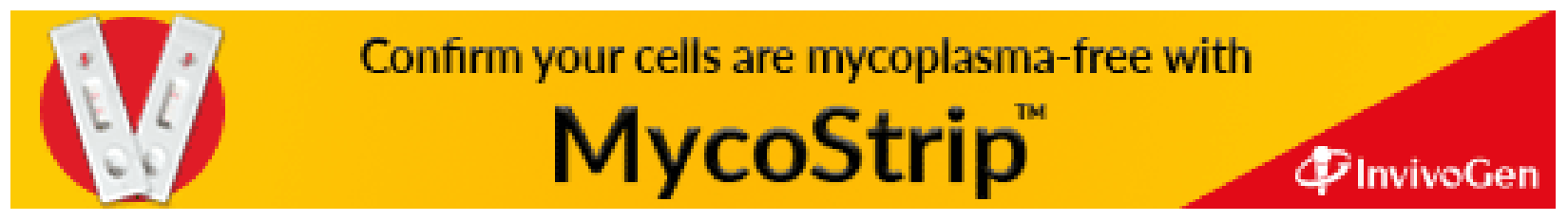

